\title{
Banner Headlines: The Māori Flag Debate in Comparative Perspective
}

EWAN MORRIS

Consider these statements.

On the one hand: ' $[\mathrm{H}] \mathrm{e}$ did not agree with flying the tino rangatiratanga flag because it argued the case of Maori sovereignty, when the Treaty was all about being equal citizens'. 'Maori enjoyed equal citizenship and did not need special treatment, either by having special Maori seats or by having a separate Maori flag fly above public venues.' 'Kiwis should come under a single flag in public places - the current ensign of New Zealand.' ${ }^{3}$

On the other hand: 'I can see no particular reason why we wouldn't fly a flag off the Auckland Harbour Bridge and indeed off other prominent government buildings, namely Parliament . . . We are flying a Maori flag, as just another small symbolic step forward in the partnership that was the treaty ... New Zealanders have a sense of pride that we are doing well in race relations, that is just another step in the partnership'. ${ }^{4}$

The speaker in both cases was John Key. The first set of comments was from February 2007, when he was Opposition leader, while the second statement was made as Prime Minister in January 2009. Key's comments nicely illustrate two perspectives in the debate about whether a Māori flag should be given official recognition by flying it alongside the New Zealand flag on public structures. Would the flying of two flags be a contradiction of the Treaty promise of equal citizenship? Would it mean special treatment for Māori, and be a threat to national unity? Or is official recognition of a Māori flag in fact a symbolic statement of support for the partnership created by the Treaty, and a sign of harmonious relations between Māori and non-Māori? This article examines such tensions in the debate over official recognition of a Māori flag, and considers what can be learned from the role that symbols of collective identity have played in other countries that are trying to come to terms with the legacies of colonization and cultural conflict.

\section{Māori flags: some history}

Debates about the flying of Māori and Pākehā flags are nothing new in Aotearoa New Zealand. Nicholas Thomas writes that: 'It is a striking feature of Aotearoa New Zealand's history that Maori have consistently and effectively embraced signs of European power and sovereignty, and made 


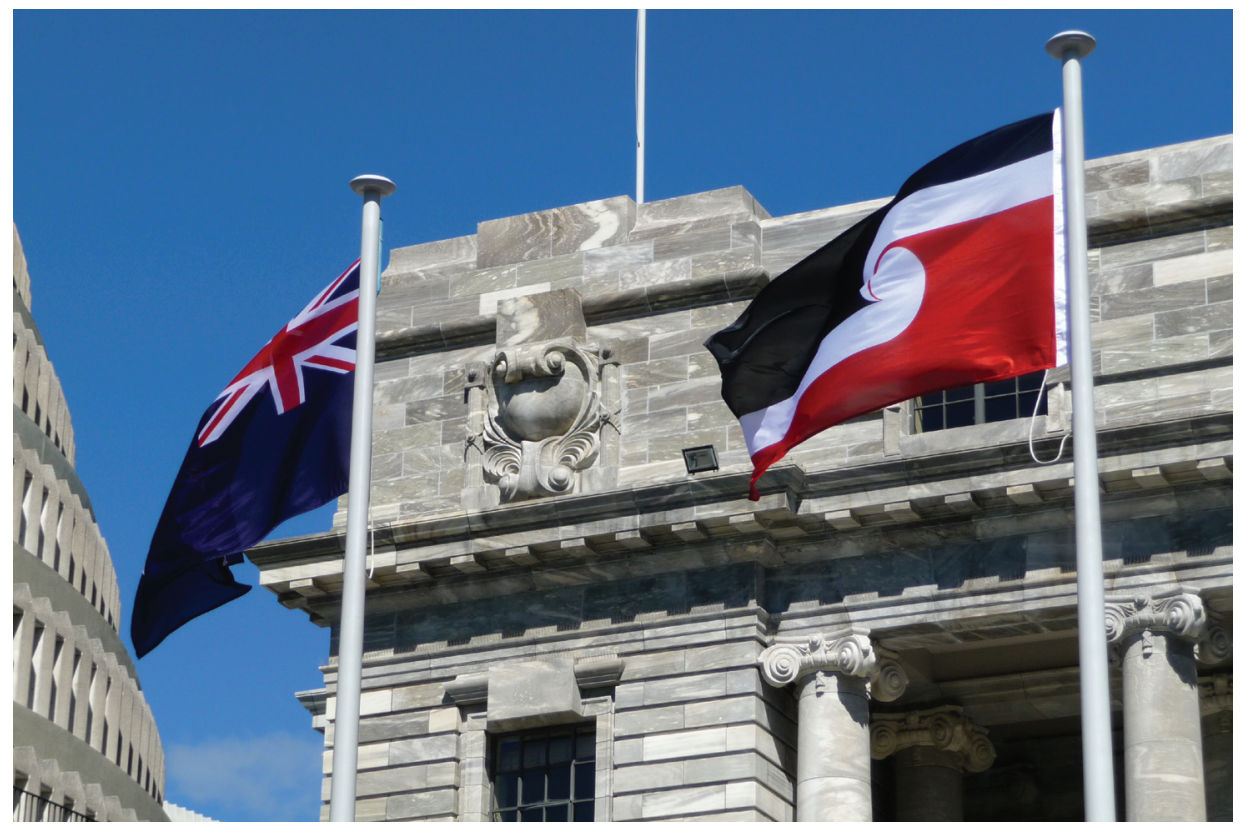

The New Zealand flag and the tino rangatiratanga flag outside Parliament on Waitangi Day 2010.

them serve their own ends. . . . An early Maori interest in flags exemplified this propensity, and no doubt was animated by the longstanding potency of fabrics and wrappings within Maori society, and the strong associations between highly valued forms, such as cloaks, and status'. ${ }^{5}$

In 1834, British Resident James Busby called together a group of Northern rangatira to choose a flag to represent New Zealand. Busby's aims were to create a flag that could be flown from New Zealand-registered ships and to encourage the chiefs to work together in some form of government. The chiefs were given three flags (designed by Rev. Henry Williams of the Church Missionary Society) to choose from, and the winning design received 12 out of 25 votes. The chosen flag was recognized by the British King and the Admiralty as the flag of New Zealand, and came to be known as the flag of the United Tribes of New Zealand. Its status since that time owes much to the fact that its selection was followed in 1835 by the Declaration of Independence of the United Tribes of New Zealand, another initiative of Busby's involving rangatira mainly from the North. The United Tribes flag has retained considerable mana up to the present day (especially, but not exclusively, in the North). It was flown during the meetings to elect the first Māori King in 1857-58, and has been used by various Māori political movements as a symbol of Māori authority and rights. ${ }^{6}$ 
Hone Heke's cutting down of the flagstaff at Kororāreka in 1844 is an early and well-known example of flags as a focus for conflict between Māori and the Crown. Heke well understood the role of flags as signs of mana. He wanted the United Tribes flag to fly alongside the Union Jack, writing to Governor FitzRoy: 'The pole that was cut down belonged to me. I made it for the Maori flag, and it was never paid for by the English'. ${ }^{7}$ Flags have also been points of contention between Māori with different allegiances. For example, during the hui at Paetai in 1857 to discuss the election of Pōtatau Te Wherowhero as the Māori King, pro-King Māori flew the United Tribes flag bearing the words 'Pōtatau, King of New Zealand', while those opposed to the election of a King flew the Union Jack. Both sides also referred in speeches to their feelings about the respective flags. ${ }^{8}$ During the New Zealand Wars Māori used flags to symbolize Māori identity and resistance to, or support for, the Crown. Political and religious movements such as the Kīngitanga and Pai Mārire, and Māori leaders such as Te Kooti, made extensive use of flags. ${ }^{9}$ Flags continued to hold great meaning for Māori through the twentieth century, and also remained a source of occasional friction within Māori communities as well as between Māori and the Crown. Anne Salmond records an incident as recently as 1970 in which a Ringatū flag was flown from the flagpole of a marae near Hastings, in honour of the visit of the Governor-General who was to open the marae. Local Māori Welfare Officers considered this to be 'a display of disloyalty to the Crown' and replaced it with a Union Jack, but the matter was soon settled by discussion. ${ }^{10}$

The nineteenth and twentieth centuries have left a rich legacy of flags with deep meaning for Māori communities, each one acting as a focus of identity and connection with the past. Until recently, however, the question of whether the state should recognize a Māori flag or flags has barely been considered. The United Tribes flag was replaced as the official flag of New Zealand by the Union Jack in 1840, and the Union Jack in turn was replaced by the current New Zealand flag in 1902. Such official acknowledgement of Māori flags as has occurred has been very limited. Since 1974, the United Tribes flag has usually been flown on the flagpole at the Waitangi Treaty Grounds, beside the Union Jack but below the New Zealand flag. ${ }^{11}$ There is also one provision in the Flags, Emblems, and Names Protection Act 1981 that specifically protects customary Māori use of the New Zealand red ensign. ${ }^{12}$ This recognizes the use by Māori of British or New Zealand red ensigns with an ancestral, hapu or marae name placed on it. Such ensigns were presented to Māori groups by the government in the nineteenth and twentieth centuries as symbols of loyalty and status. ${ }^{13}$ 


\section{The origins of the tino rangatiratanga flag}

In 1982, a group of Māori activists travelled to Australia to support Australian Aboriginal protests at the time of the Brisbane Commonwealth Games. Arriving in Sydney, they spent some time with the Aboriginal community in the inner-city suburb of Redfern. A member of the group recalled later that:

... the most standout sight in the whole suburb was the Aboriginal Flag. It was everywhere - on t-shirts, on flagpoles, on hats, on bags, on walls, and even spraypainted onto a couple of broken down cars on the road. A stunning and powerful symbol that required no words, no explanations, no description. It was just there - in your face, behind your back, beneath your feet, waving above your head, and watching you from the sidelines. You just couldn't ignore it. The flag. It blew us away.

I remember vowing that one day we would have a flag of our own - a symbol of our own struggle for Maori Independence. ${ }^{14}$

Inspired by the Aboriginal example, the group Te Kawariki in 1989 organized a competition to design a Māori flag. The group was looking for 'something new, something free from colonial symbolism'. They accordingly dismissed the United Tribes flag 'because it wasn't a Maori design . . . [and] it represented the patronising control that Pakeha have always sought to exert over Maori independence'. They were also uninspired by the entries they received in the competition, so instead they chose a design by Kawariki members Linda Munn, Hiraina Marsden and Jan Dobson-Smith. The flag was launched in 1990. It was simply called the Māori flag, but it soon also became known as the tino rangatiratanga flag because it was seen as symbolizing the tino rangatiratanga (self-government, sovereignty or self-determination) guaranteed to Māori in the Treaty of Waitangi. ${ }^{15}$ In this article it will be referred to as the tino rangatiratanga flag since that is the name by which the flag is now most commonly known, and because its claim to be the Māori flag is still disputed. ${ }^{16}$

According to Kawariki member Hilda Halkyard-Harawira, writing in 1997: 'Maori reaction [to the flag] has been mixed. There were those who picked it up. Others preferred to design their own flag. Then there were those both Maori and tauiwi [non-Māori] who downright hated the flag ... The Maori flag walks its own walk. I have come to realise the Maori flag will be the centre of controversy for awhile. Controversy creates tension and debate ... In the end, no-one can force anybody to stand under a flag they do not respect. People have the right to stand under the flag of their choice. The Maori Flag offers a choice of options' ${ }^{17}$ Ten years after Halkyard-Harawira wrote these words, the tino rangatiratanga flag was to become the focus of a new controversy and new questions about what choosing to fly the flag means. 


\section{The path to official recognition of a Māori flag}

The question of whether the state should recognize a Māori flag was put on the national agenda in 2007, when the group Te Ata Tino Toa wrote to Transit New Zealand asking for the tino rangatiratanga flag to be flown from the Auckland Harbour Bridge on Waitangi Day. Te Ata Tino Toa spokesperson Teanau Tuiono explains that: 'A couple of us have been driving over the Harbour Bridge and we saw all manner of flags up there - saw the Sri Lankan flag, the Lebanese flag, and all these other flags from wīwī and wāwā, and we thought, be pretty good to see our flag up there as well'. ${ }^{18}$

For Te Ata Tino Toa, the call to fly the flag on the bridge was a way of providing 'recognition of the unique role of Maori', ${ }^{19}$ while also drawing attention to shortcomings in New Zealand's record on indigenous human rights. ${ }^{20}$ Transit declined the request on the grounds that its policy was to fly only the flags of countries recognized by the United Nations on their national days. Prime Minister Helen Clark defended Transit's decision, and while she said that the flag could fly on the bridge and in other public places the following year if there was enough public support, nothing came of this. ${ }^{21}$ It was subsequently pointed out to Transit that they had in fact agreed to a number of flags that did not represent recognized nation-states being flown on the bridge, including the European Union flag and the America's Cup 'Loyal' flag. As a result, Transit changed its policy so that in future only the New Zealand flag could be flown. ${ }^{22}$ Te Ata Tino Toa's request was repeated and again declined in $2008 .{ }^{23}$ In both 2007 and 2008, Te Ata Tino Toa responded to Transit's refusal to fly the flag by calling on supporters to fly the tino rangatiratanga flag as widely as possible on and around Waitangi Day. ${ }^{24}$

In December 2008, Te Ata Tino Toa wrote to the new Minister of Māori Affairs, Māori Party co-leader Pita Sharples, requesting that he intervene to try to get the flag flying from the bridge on Waitangi Day 2009. ${ }^{25}$ This time, they received a more positive response. In January 2009, Pita Sharples said: 'I want that flag up there . . . [P]utting the Tino Rangatiratanga flag up alongside the New Zealand flag shows a willingness by New Zealand to recognise the bicultural nature of our foundation which is recognised on Waitangi Day. That's all it's about. They can take it down after Waitangi Day'. ${ }^{26}$ Prime Minister John Key then announced that there would be consultation with Māori to determine which flag would represent them and be flown from the Auckland Harbour Bridge and public buildings on Waitangi Day from 2010. ${ }^{27}$

In July 2009 the consultation process began, and 21 hui were held across the country, with the consultation being led by Māori Party MP (and member of Te Kawariki) Hone Harawira. Māori views were sought about which flag should be chosen as a national Māori flag, and on what days it should be 
flown. ${ }^{28}$ With regard to the first question, four options were presented: the tino rangatiratanga flag, the United Tribes flag, the New Zealand flag and the New Zealand red ensign. A range of other flags had been considered by Te Puni Kōkiri (the Ministry of Māori Development), but these flags were apparently rejected as being too tied to the colonial past or to particular iwi, or due to intellectual property rights issues. ${ }^{29}$ On the second question, despite the initial discussion having been about flying the flag on Waitangi Day, Māori were asked whether a national Māori flag should be flown only on Waitangi Day or on Waitangi Day and other significant national occasions.

A total of 1220 oral and written submissions were received during the consultation process, and $80 \%$ of them chose the tino rangatiratanga flag as the national Māori flag. Another 16\% chose the United Tribes flag. Among the arguments in favour of the tino rangatiratanga flag were that it was designed by Māori for Māori; represents Māori unity, self-determination and mana; and is future focused. Supporters of the United Tribes flag emphasized its historical significance. On the question of when the flag should be flown, $72 \%$ of those who answered the question thought it should fly on Waitangi Day and other significant occasions. ${ }^{30}$

On 14 December 2009, Cabinet accepted Pita Sharples' recommendation that the tino rangatiratanga flag should be flown as the national Māori flag on Waitangi Day on the Auckland Harbour Bridge and some government buildings. ${ }^{31}$ In announcing the decision, John Key said that the Māori flag would fly alongside the New Zealand flag, rather than replacing it, to recognize the Crown-Māori relationship, while Pita Sharples said that flying the Māori flag 'is a simple way to recognise the status of Maori as tangata whenua and their contribution to New Zealand'. Both men emphasized that there would be no change to the status of the New Zealand flag. ${ }^{32}$ In answer to the criticism that the tino rangatiratanga flag symbolized Māori sovereignty and protest, Key said that the flag meant different things to different people: 'The message I take from it is potential and hope'. ${ }^{33}$

The tino rangatiratanga flag has not, so far, been recognized in the Flags, Emblems, and Names Protection Act, nor have any plans been announced for it to fly on days other than Waitangi Day, although there are indications that both of these options may be considered in future. ${ }^{34}$ Official guidelines for flying the flag have been developed. These state that flying the New Zealand flag and the Māori flag together on Waitangi Day is encouraged, and that the Māori flag should be flown in a way that respects the status of both flags and expresses a spirit of mutual respect and nationhood. If the two flags are flown from a single flagpole, 'the New Zealand flag should fly above the national Māori flag in order to respect its status as the symbol of the Realm, Government, and people of New Zealand', but where there are multiple flagpoles the two flags should fly from equal height. ${ }^{35}$ 
On Waitangi Day 2010, the tino rangatiratanga flag was flown at a number of locations, including the Auckland Harbour Bridge, the Beehive, the forecourt of Parliament, Government House, Premier House, Te Papa Tongarewa (the Museum of New Zealand), and the Wellington offices of several government departments. ${ }^{36}$ However, the Waitangi National Trust decided not to fly the flag at the Waitangi Treaty Grounds, due at least in part to opposition from nearby Te Tii marae and the preference of many Northern Māori for the United Tribes flag. ${ }^{37}$ Some other marae also decided against flying the tino rangatiratanga flag, ${ }^{38}$ as did some local councils. ${ }^{39}$ Dunedin appears to be the only city that officially flies the tino rangatiratanga flag on Waitangi Day. ${ }^{40}$

\section{Themes in the Māori flag debate}

Thus, a simple request to fly the tino rangatiratanga flag from the Auckland Harbour Bridge on Waitangi Day triggered a process that has led to official recognition of a national Māori flag. The Government's response has been able to evolve rapidly at least in part because there has been no opposition from within Parliament. ${ }^{41}$ However, the issue has not been free from controversy, and many people did not support the Government's decision. An opinion poll in September 2009 found that $40 \%$ of respondents agreed and $51 \%$ disagreed 'that a chosen Māori flag should fly beside the New Zealand flag on all official occasions and days of national significance'. However, a small majority of Māori and Pacific respondents, and of respondents aged 18-34 agreed with flying the flag. ${ }^{42}$ A poll of Māori in January 2010 found that 53\% agreed that Māori should have a separate flag and 58\% recognized the tino rangatiratanga flag as 'the Māori flag'. ${ }^{43}$ There are real points of contention between those who support and those who oppose giving official recognition to a Māori flag. These include disagreements about whether symbolic recognition of difference is inimical or essential to the development of a cohesive society. ${ }^{44}$

Many of those who have commented on the issue see official recognition of a Māori flag as divisive. Those who take this view say that New Zealand is one nation, and should fly one flag to represent all its people. Flying a Māori flag, they claim, gives special recognition to Māori, privileging them above other groups in society. Moreover, it is argued, New Zealand is a multicultural society, so if Māori are to be represented separately, why not do the same for all New Zealand's other ethnic groups? The New Zealand flag represents Māori as well as all other New Zealanders: 'The New Zealand flag represents everyone, Maori and Pakeha and Indian and Scots and everyone else in our multicultural country. The Maori flag represents only one part of our history and country, therefore it's inappropriate to fly it unless you intend flying the flags of every other culture in New Zealand' ${ }^{45}$ 
Alternatively, some people believe that if the current flag does not properly represent all New Zealanders, it should be changed so that it better reflects modern New Zealand society, in preference to flying a separate Māori flag. Another argument put forward by opponents of flying a Māori flag is that the Treaty was about creating one people, and Waitangi Day should be a day to celebrate national unity: "Flying two flags, one for "us" and one for "them" . . . isn't really celebrating the spirit of Waitangi Day, which is supposed to commemorate the "togetherness" of our nation". ${ }^{46}$ Many people also object specifically to the tino rangatiratanga flag, which they associate with radicalism, separatism and divisiveness, and see as too closely linked with the Māori Party: 'the Tino flag was created out of spite anyhow. What does your flag mean to me? Protest, and conflict, as that is all I see your flag flying at! ${ }^{47}$

Supporters of flying the Māori flag strongly disagree with the view that this would be a divisive act. They argue that flying two flags recognizes New Zealand's bicultural foundations and the Treaty relationship between Māori and the Crown. It thus represents the very things that make Aotearoa New Zealand a distinctive national community: 'How best to commemorate Waitangi Day if we can't even put [up] the Maori flag to signify the Day? Isn't Waitangi Day . . . about the treaty between the two parties? . . In fact it goes to show that NZ is a country where people don't judge anybody and Kiwis live harmoniously side by side'. ${ }^{48}$ Flying a Māori flag, they maintain, is an expression of inclusiveness; it represents an acceptance of diversity and difference within New Zealand society. They see official recognition of a Māori flag as an acknowledgement of the unique position of Māori as tāngata whenua, a celebration of Māori history and culture, and a symbol of respect and mana: 'It doesn't represent division, it represents Maori self-determination and recognition of this will only move Maori forward. Denying the flying of the flag only indicates more assimilation. I love being Maori and different'. ${ }^{49}$ They also argue that the Māori flag is about being pro-Māori, not about being against Pākehā or anyone else: 'There is no intention, by flying the Maori flag to cause any resentment, concern or otherwise. The only intention in flying a Maori flag is to recognise and assert our indigenous heritage ... We are the indigenous culture of Aotearoa, and it is time we be recognised as such'. ${ }^{50}$ Furthermore, it is said, non-Māori are happy to celebrate and even adopt as national symbols other aspects of Māori culture, such as haka and the national anthem sung in Māori, so there should be nothing threatening about recognizing a Māori flag. ${ }^{51}$

Despite their differences, there are also points on which both sides largely agree. National unity was a key theme for those opposing recognition of a distinct Māori flag, but it was also a theme that came through strongly from those who supported flying a Māori flag alongside the New Zealand flag. 
Most agree that New Zealand should be represented as a united country, and that the flying of flags should promote harmony rather than conflict. Most also agree that Māori have something to gain from recognition of their flag, although one side see Māori as gaining long-overdue mana and respect while the other side believe Māori are gaining undue privilege. There has been relatively little questioning of these assumptions in the public debate.

Certainly, some have questioned the relevance and value for Māori (as well as for the country as a whole) of focusing on flags, particularly in a time of economic recession. Some within the Labour Party have also asked whether the Māori Party is being bought off with cheap promises of flags, while failing to shift the Government's position on more substantive issues such as Māori seats on the Auckland super-city council. ${ }^{52}$ But few have been asking whether official recognition of a Māori flag is a distraction from larger and more difficult issues of reshaping the relationship between Māori and the state, or an attempt to assimilate and contain Māori demands for self-determination. A rare example of such questioning came from Emily Bailey, commenting on the Aotearoa Independent Media website. In response to the Government's acceptance in principle of flying a Māori flag on public buildings, she asked: '[W]hat does it mean if [the tino rangatiratanga flag] replaces the national New Zealand flag or even flies beside it? . . Do not be surprised if, like with the Seabed and Foreshore Act and with current water ownership legislation, we see the tino rangatiratanga flag appropriated out from underneath us . . The tino rangatiratanga flag is important to Maori. It speaks a thousand words in one image and holds a huge history of struggle for our right to be . . . We need to speak up to save our flag and everything it stands for from further colonial appropriation'. ${ }^{53}$

There are, in fact, some commentators who would like nothing better than to appropriate the tino rangatiratanga flag as a new national flag of New Zealand, as well as some who argue that the United Tribes flag should be New Zealand's national flag. ${ }^{54}$ As an article in the New Zealand Herald noted, 'it seems whenever the Tino Rangatiratanga flag is mentioned debate follows over whether the country's national flag represents the nation today'. ${ }^{55}$ Much of the debate on the national flag focuses on the appropriateness of having a flag that emphasizes New Zealand's ties with Britain and is easily confused with Australia's. However, those who advocate changing the flag also often argue that the current flag does not adequately represent Māori because the Union Jack symbolizes the colonization of New Zealand and because the flag includes no symbols with significance for Māori. The suggestion that the flag and other national symbols need to be changed to better represent Māori has been around at least since the 1980s, ${ }^{56}$ and has emerged again in the wake of the recent Māori flag debate..$^{57} \mathrm{~A}$ surprising number of those who opposed the decision to fly a Māori flag alongside 
the New Zealand flag were willing instead to see the New Zealand flag changed so that it acknowledges Māori as well as more recent arrivals. For many people, creating a new, more representative flag was a better way of celebrating diversity than flying two flags. ${ }^{58}$ Interestingly, even members of Te Kawariki have supported the creation of a new flag that can unite Māori and non-Māori. Hilda Halkyard-Harawira has written that 'Aotearoa is Maori land. However a flag that would unify Maori and tauiwi should fly. It could represent a mutual liberation from our colonial past'. ${ }^{9}$

\section{Some overseas comparisons}

Declaring his opposition to the Government's decision to fly the tino rangatiratanga flag on Waitangi Day, New Zealand First party leader Winston Peters asked: 'Which self-respecting nation has two flags flying anywhere? ... There's one flag in Australia, and one flag in Canada, and in every other First World nation . . . they have one flag' ${ }^{60}$ Some supporters of recognition for a Māori flag, on the other hand, have pointed to examples such as the official recognition of the Aboriginal and Torres Strait Islander flags in Australia, ${ }^{61}$ and the flying of the flags of the constituent nations of the United Kingdom together with the Union Jack, ${ }^{62}$ as precedents for recognizing a national Māori flag. New Zealand is certainly not the only country in which flags have been a focus for debates about identity and sovereignty, and it may be instructive to consider some flag debates overseas.

It is true that, while the Union Jack is the flag of the whole of the United Kingdom, the flags of England, Scotland and Wales are flown on public buildings in those countries on at least some days of the year. ${ }^{63}$ This reflects the fact that people in the United Kingdom can have dual identities as both Scottish (say) and British. However, the English, Scottish and Welsh flags represent geographically-bounded nations within a wider union, rather than people with a distinct ethnic or national identity who are dispersed across the whole of a nation-state. The Scottish flag, for example, is meant to represent all the inhabitants of Scotland, regardless of ancestry. ${ }^{64} \mathrm{~A}$ comparable situation could have been found in New Zealand had the rohe pōtae of the Kīngitanga and Tūhoe remained in existence, ${ }^{65}$ with their own flags representing self-governing territories; as it is, however, there is a significant difference in the contexts for the flying of national flags in Britain and the flying of a Māori flag in New Zealand.

The situation is rather different in the deeply-divided society of Northern Ireland ${ }^{66}$ There, symbols are highly contentious, inextricably connected with the competing identities of the Protestant majority, who overwhelmingly see themselves as British and want to remain part of the United Kingdom, and the Catholic minority, most of whom see themselves as Irish and believe that Northern Ireland's long-term future lies in a united Ireland. For the 
most part, Protestants identify with the Union Jack, Catholics with the Irish tricolour. All of the main options for flying flags on public buildings in Northern Ireland - flying the Union Jack alone, flying the Union Jack and the tricolour together, flying no flag at all, or flying a new, neutral flag for Northern Ireland - are problematic in different ways, and would leave some political factions unhappy. So long as Northern Ireland's people remain divided along ethnic-religious lines, and its political status remains unresolved, it is hard to see any consensus emerging as to the flying of flags on public buildings. Neither Britain nor Northern Ireland, therefore, is a particularly good model for New Zealand to consider in relation to flag-flying.

Australia is a much closer model, and much of the impetus for recognizing a Māori flag has come from the official recognition of the Aboriginal and Torres Strait Islander flags in Australia. The Aboriginal flag was first flown in 1971, and it quickly became a powerful symbol of Aboriginal identity and political struggle. In 1994, the Aboriginal athlete Cathy Freeman carried the Aboriginal flag in her victory lap after winning the 400 metres final at the Commonwealth Games. Although this action was criticized by some at the time, it seems to have played an important role in changing the attitudes of many non-Aboriginal Australians towards the Aboriginal flag. It also dovetailed with the Labor Government's process of reconciliation with indigenous peoples, and in 1995 two official reports on Aboriginal social justice issues included among their recommendations the official recognition of the Aboriginal flag and the more recently-created Torres Strait Islander flag. ${ }^{67}$ Accordingly, in July 1995 the two flags were proclaimed as official flags of Australia under the Flags Act $1953 .{ }^{68}$

As in New Zealand, there was debate in Australia about whether official recognition of indigenous flags was inclusive or divisive. Prominent Aboriginal leader and Chair of the Council for Aboriginal Reconciliation, Pat Dodson, called it 'an inclusive and historic act ... . [which] says to Aboriginal and Torres Strait Islander people: "You are a valued and unique part of the fabric of our nation." " ${ }^{69}$ Then Leader of the Opposition John Howard, on the other hand, saw it 'not as an act of reconciliation but as a divisive gesture'.70 Despite this statement, Howard did not reverse the decision when he became Prime Minister. Opinion polls showed that most Australians supported the decision, and the Aboriginal and Torres Strait Islander flags have become widely flown on local, state and federal government buildings. However, the designer of the Aboriginal flag, Harold Thomas, was not entirely happy. Apart from the issue of his intellectual property rights in the flag, which were confirmed in the Federal Court in $1997,{ }^{71}$ he was concerned that the flag would 'lose its potency' as a symbol of Aboriginal struggle. ${ }^{72}$ This does not seem to have happened, however, and the flags remain potent symbols 
of Aboriginal and Torres Strait Islander identities and protest regardless of their recognition by the state. Whether that recognition has truly assisted in moving towards justice for indigenous people and reconciliation with nonindigenous Australians is debatable. But for a country that systematically excluded and marginalized indigenous people for so long, symbolic gestures of acknowledgement and respect can carry great weight, as former Prime Minister Kevin Rudd's long-awaited apology to indigenous Australians for historical injustices in 2008 showed.

My final overseas example is that of another set of islands in which the indigenous Polynesian inhabitants have been struggling to assert their rights and identity in a state dominated by a non-indigenous majority. The flag of the independent kingdom of Hawai' $i$ that was overthrown by settler interests in 1893 has been appropriated and used successively as the flag of the Republic, the Territory, and now the US state of Hawai' $i{ }^{73}$ Despite this appropriation, it has remained a powerful symbol of Hawaiian identity and struggle. Since the late nineteenth century, native Hawaiians have made flag quilts, often incorporating symbols of the monarchy and the phrase 'Ku'u Hae Aloha' (My Beloved Flag), as assertions of indigenous Hawaiian patriotism. ${ }^{74}$ In the public sphere, Hawaiian sovereignty advocates often fly the Hawaiian flag upside down to symbolize a nation in distress. ${ }^{75}$ In recent years some Hawaiian nationalists, wanting a symbol less reminiscent of the British and American flags, have promoted what they claim is the original Hawaiian flag as an alternative "Kānaka Maoli", or native Hawaiian, flag. ${ }^{76}$ However, while the Kānaka Maoli flag has grown in popularity, it has not replaced the Hawaiian flag as a symbol of Hawaiian sovereignty.

\section{Conclusion}

Each of the overseas situations discussed above illustrates a different point about the role of flags and other symbols of collective identity in societies grappling with tensions over histories, sovereignties and identities. In Britain the flying both of flags representing distinct national identities and of the Union Jack representing the United Kingdom state suggests the possibility of accommodating dual (or indeed multiple) identities within a state. However, the case of Northern Ireland is a caution against an overly-utopian expectation that it is easy and natural to accept pluralism of symbols and of the identities they represent. Where different symbols represent different ethnic groups living side by side with each other, with very different historical memories and aspirations for the future constitutional position of the territory in which they live, any approach to the use of symbols by the state (including maintaining the status quo or adopting supposedly neutral symbols) is likely to be seen as advantaging one group and prejudicing the other. Fortunately, New Zealand is very far from being in a similar position 
to Northern Ireland. Here, a widely shared sense of New Zealand identity is able to coexist with other identities, even if a multiplicity of identities and loyalties is seen as a challenge by those who subscribe to a 'one New Zealand' ideology.

The cases of Australia and Hawai'i raise different issues from those that arise in the United Kingdom. In both cases, the state has given official recognition to indigenous flags, although in the Australian case the flags are recognized as symbols of indigenous identities while in the case of Hawai' $i$ an indigenous flag has been appropriated to represent the state itself. What does it mean for the state to recognize or even appropriate symbols of indigenous identity and struggle? Does this enhance the mana of indigenous peoples, or is it simply a form of assimilationism? Certainly, it seems that Aboriginal and Torres Strait Islander people, and native Hawaiians, continue to use their flags to symbolize their autonomy and political struggle despite the use of these flags by the state. The Australian and Hawaiian situations also suggest questions about whether recognition of the symbols of historically-marginalized groups is merely window-dressing which distracts from more important issues. For example, what role can symbols play in helping to reconcile societies that are trying to come to terms with the legacies of injustice, inequality and ethnic conflict? Can such recognition really assist in moving towards societies which are more inclusive and better able to accommodate difference? These are important questions for Aotearoa New Zealand, too, to consider.

Across the world, flags and other symbols have been contentious at times because they have no inherent or fixed meaning, but instead have historical and contemporary associations that vary between different individuals and groups in society. They also mark boundaries of inclusion and exclusion, differentiating 'us' from 'them', and, in the case of national or state symbols, they inevitably raise questions of sovereignty and power. All of these factors can make discussions about symbols difficult - sometimes, as in Northern Ireland, almost paralysingly so - but such discussions are important for what we can learn about each other in the course of them. Indeed, prompting debate and discussion seems to have been one of the purposes for which the tino rangatiratanga flag was developed in the first place: 'If the Maori flag can stimulate debate,' wrote Hilda Halkyard-Harawira, 'then she is a powerful educator'. ${ }^{77}$ Some of the more thoughtful responses to the proposal to fly a Māori flag on the Auckland Harbour Bridge and elsewhere have seen it as an opportunity to open up dialogue about Aotearoa New Zealand's history, and about the place of Māori and non-Māori in this country. ${ }^{78}$ If the conditions are right, such discussions can make people aware of other perspectives on questions of nationhood and identity in a way that helps to bridge social divisions and not entrench them. A bridge may, indeed, be the most symbolically appropriate place of all on which to fly a Māori flag. 
1 'Key Ready to Face Music at Waitangi', New Zealand Herald (NZH), 3 February 2007 (viewed online at www.nzherald.co.nz, accessed 18 November 2010).

2 'Key Leaves the Suit at Home', Dominion Post (DP), 6 February 2007 (accessed via the Newztext database).

3 'Maori Flag May Fly on Bridge', DP, 7 February 2007 (accessed via the Newztext database).

4 'Key Says Yes to Maori Flag Over Bridge, Parliament', Fairfax Media news story, 14 January 2009 (viewed online at www.stuff.co.nz, accessed 18 November 2010).

5 Nicholas Thomas, 'Introduction', in Nicholas Thomas, Mark Adams, Lyonel Grant and James Schuster, Rauru: Tene Waitere, Maori Carving, Colonial History, Dunedin, 2009, p.25.

6 Judith Binney, 'Two Communities, 1820-1839', in Judith Binney, Judith Bassett and Erik Olssen, The People and the Land = Te Tangata me te Whenua: An Illustrated History of New Zealand 1820-1920, Wellington, 1990, pp.29-30; Esther McGill, 'Flags as Power Play in Maori and Pakeha Relations', Honours long essay, Victoria University of Wellington, 2006, pp.22-24; Ministry of Culture and Heritage, 'History of the New Zealand Flag: Flag of the United Tribes of New Zealand (1834-1840)', www.mch.govt .nz/nzflag/history/united.html, accessed 14 February 2010. For an example of the United Tribes flag being linked to Māori aspirations for greater autonomy in the early twentieth century, see Judith Binney, 'Amalgamation and Separation, 1890-1920', in Binney, Bassett and Olssen, p.205.

7 Heke to FitzRoy, 19 July 1844, Duplicate Despatches to Secretary of State 1840-1855 G 30/6, National Archives, quoted in Judith Binney, 'Kawanatanga and Rangatiratanga, 1840-1860', in Binney, Bassett and Olssen, p.80. The later history of the flagstaff at Kororāreka is discussed in Vincent O'Malley, “'A Living Thing”: The Whakakotahitanga Flagstaff and its Place in New Zealand History', Journal of New Zealand Studies, 8 (2009), pp.41-60. For a less dramatic, but still significant, example of differences between Māori and the Crown over flags, see Judith Binney, Encircled Lands: Te Urewera, 1820-1921, Wellington, 2009, pp.425-27.

8 Evelyn Stokes, Wiremu Tamihana: Rangatira, Wellington, 2002, pp.142-52. For another example of conflict between Māori over flags, see Judith Binney, Redemption Songs: A Life of Te Kooti Arikirangi Te Turuki, Auckland, 1995, pp.40-46.

9 Rebecca Rice, 'Hauhau and other Rebel Flags: Histories of Exchange, Acculturation and Appropriation in Nineteenth-Century New Zealand', Journal of New Zealand Art History, 23 (2002), pp.43-54; McGill, pp.29-39.

10 Anne Salmond, Hui: A Study of Ceremonial Gatherings, 2nd edn, Auckland, 1976, p.52, citing Hawke's Bay Herald Tribune, 12 June 1970.

11 Ministry of Culture and Heritage, 'Waitangi Flagpole' and 'Flags Flying on Waitangi Day', www.nzhistory.net.nz/media/photo/waitangi-flagpole and www.nzhistory.net.nz /media/photo/flags-flying-waitangi-day, accessed 14 February 2010.

12 Flags, Emblems and Names Protection Act 1981, s 9(3).

13 McGill, pp.41-44.

14 Quoted in H.Halkyard-Harawira, 'The Maori Flag - A Symbol of Liberation', in Te Kawariki, 20 Yrs of Protest Action 1979-1999, Kaitaia, 1999, p.55. The article does not identify the source of this quote, but the speaker may have been Hone Harawira. The person quoted refers to 'Ripeka Evans, Hilda Halkyard-Harawira and I' having been invited to support the Commonwealth Games protest. A planned visit to Brisbane by Hone Harawira and Ripeka Evans, in advance of the Commonwealth Games protests, was reported in 'Maori Protest Visitors', Sunday Mail, 28 April 1982 (accessed at 
www.kooriweb.org/foley/images/history/1980s/82games/cm28apr82.html, 18 November 2010).

15 Hilda Halkyard-Harawira reports that, two years after the flag was launched, 'I noticed Pita Paraone, a well known conservative Crown employee, wearing a white polo tshirt, with an emblem of the Maori flag and underneath it was the text "tino rangatiratanga". A kohanga reo in his area were selling them as fundraisers, and he was very proud to wear it. From then onwards, the flag also became known as the tino rangatiratanga flag.' Halkyard-Harawira, p.57.

16 The question of whether or not the flag should be referred to as the Māori flag caused difficulties when the brochure for the consultation process on a national Māori flag (discussed below) was being developed: email from Jaewynn McKay to Lucy Te Moana and others, 29 June 2009; email from Hone Harawira to Claire Mason and others, 10 July 2009; email from Te Puni Kōkiri to Hone Harawira, 11 July 2009 (documents released under the Official Information Act 1982). See also 'Harawira Email Swore at Bureaucrats', DP, 24 December 2009 (viewed online at www.stuff.co.nz, accessed 18 November 2010).

17 Halkyard-Harawira, pp.57-58.

18 Teanau Tuiono on 'Native Affairs', Maori Television, 2 June 2008 (viewed at www .indigenousportal.com/Politics/Te-Haki-The-M\%C4\%81ori-flag.html, accessed 29 August 2009).

19 Teanau Tuiono to the Board of Transit NZ, 20 December 2007 (available at www .converge.org.nz/pma/trflag08.htm, accessed 18 November 2010).

20 Teanau Tuiono on 'Breakfast', TV One, 6 February 2008 (viewed at www.youtube.com accessed 29 August 2009).

21 'Maori Flag May Fly on Bridge', DP, 7 February 2007 (accessed via the Newztext database).

22 'Transit Flies New Policy: Official NZ Flag Only', NZH, 30 May 2007 (viewed online at www.nzherald.co.nz, accessed 18 November 2010); Transit NZ media release, 29 May 2007, www.waikato.transit.govt.nz/news/MediaReleaseView.do?MediaReleaseId=nz.govt .transit.transweb.content.news.MediaRelease-11685, accessed 28 February 2010; Tom Bennion, 'Flying the Flag', Te Karaka, 38, (Autumn 2008), p.34.

23 Teanau Tuiono to the Board of Transit NZ, 20 December 2007; Bryan Jackson, Acting Chair, Transit NZ, to Teanau Tuiono, 5 February 2008 (available at www.converge.org. nz/pma/trflag08.htm, accessed 18 November 2010).

24 See 'Waitangi Day: Maori Flags over Aotearoa', February 2007, and 'Fly the Flag: Competition, Letters and Donations', February 2008, at www.converge.org.nz/pma/ in010207.htm and www.converge.org.nz/pma/trflag08.htm, accessed 20 February 2010. For analysis of media coverage of the issue in 2007, see Jenny Rankine, Raymond Nairn, Angela Moewaka Barnes, Mandi Gregory, Hector Kaiwai, Belinda Borell and Tim McCreanor, Media \& Te Tiriti o Waitangi 2007, Auckland, 2008, pp.37-39.

25 Sina Ana Brown-Davis to Pita Sharples, 18 December 2008, put out as a press release by Te Ata Tino Toa, www.scoop.co.nz/stories/PO0812/S00242.htm, accessed 28 February 2010.

26 'Sharples Raises Stakes in Maori Flag Row', NZH, 10 January 2009 (viewed online at www.nzherald.co.nz, accessed 18 November 2010).

27 'Key Says Yes to Maori Flag Over Bridge, Parliament', Fairfax Media news story, 14 January 2009 (viewed online at www.stuff.co.nz, accessed 18 November 2010).

28 Te Puni Kōkiri, Kia Whakamana he Haki Māori/Recognising a National Māori Flag, consultation brochure, July 2009. 


\section{Journal of New Zealand Studies}

29 Te Puni Kōkiri, memo to Minister of Māori Affairs, 3 June 2009 (released under the Official Information Act); Hone Harawira, 'Flag it Shane . . . You've Had Your Day', Northland Age, 21 July 2009 (available at www.tokerau.co.nz/index. php?pag=cms\&id=233\&p=flag-it-shane.html, accessed 28 February 2010).

30 Reports of flag consultation hui and summary of the results of the consultation process (released under the Official Information Act).

31 Minute of Cabinet decision, 14 December 2009, CAB Min (09) 44/15 (released under the Official Information Act).

32 John Key and Pita Sharples, 'Maori Flag Chosen to Fly on Waitangi Day', 14 December 2009, press release (viewed online at www.beehive.govt.nz, accessed 14 December 2009).

33 'Maori Leaders Clash Over Flag's New Role', NZH, 15 December 2009.

34 Pita Sharples' paper to Cabinet Domestic Policy Committee, 8 December 2009 (released under the Official Information Act), refers in paragraph 22 to the possibility of amending the Flags, Emblems and Names Protection Act 1981 'at some future time, based on the development of practice arising from the current proposal', while paragraph 24 refers to the focus of flying the flag being 'on Waitangi Day in the first instance' (emphasis added). See also 'Maori Leaders Clash Over Flag's New Role', NZH, 15 December 2009: 'Dr Sharples said he hoped the new flag would be flown on other occasions.'

35 Ministry of Culture and Heritage and Te Puni Kōkiri, 'Guidelines for Flying the National Māori Flag', www.mch.govt.nz/nzflag/maori-flag.html, accessed 21 December 2009.

36 'PM Cautions Harawira Against Flogging the Flag', NZH, 5 February 2010; 'Key's Waitangi Security Boosted', DP, 5 February 2010.

37 Radio New Zealand, 'Maori Flag Will Not Fly at Waitangi Treaty Grounds', 30 January 2010 (viewed online at www.radionz.co.nz, accessed 1 February 2010); 'PM Cautions Harawira Against Flogging the Flag', NZH, 5 February 2010; 'United Tribes Flag Rules in Waitangi', New Zealand Press Association, 5 February 2010 (viewed online at www. voxy.co.nz, accessed 8 February 2010). At its meeting on 26 February 2010, the Waitangi National Trust Board reached the provisional conclusion that the tino rangatiratanga flag should not fly on the flagstaff on the Treaty grounds until it becomes an official New Zealand flag, although the matter should be the subject of ongoing discussion and a clear decision should be made before next Waitangi Day: extract from minutes of Waitangi National Trust Board General Meeting, 26 February 2010 (released under the Official Information Act).

38 'Ngai Tahu Reject Flag as "Trouble", Press (Christchurch), 5 February 2010; 'Local Flags to Fly at Marae on Waitangi Day', Nelson Mail, 5 February 2010 (both viewed online at www.stuff.co.nz, accessed 18 November 2010).

39 A proposal to fly the tino rangatiratanga flag from the Civic Centre in Rotorua was rejected by the Rotorua District Council's Te Arawa Steering Committee: 'Kaumatua Says No to Flying Maori Flag', Daily Post (Rotorua), 4 February 2010 (viewed online at www.rotoruadailypost.co.nz, accessed 18 November 2010). The Manukau City Council reconsidered its Flag Policy, developed in 2008 in response to calls for it to fly the tino rangatiratanga flag on Waitangi Day. It voted to retain the existing policy of flying only the New Zealand and City Council flags, and the flags of its sister cities and visiting overseas delegations: 'Flag Debate "Dismay"', Howick and Pakuranga Times, 4 February 2010 (viewed online at www.times.co.nz, accessed 4 February 2010); 'Maori Flag Bid Does not Fly with Council', Manukau Courier, 5 February 2010 (viewed online at www .stuff.co.nz, accessed 5 February 2010).

40 'Dunedin Flies Solo on Maori Flag', Otago Daily Times, 6 February 2009 (viewed online at www.odt.co.nz, accessed 18 November 2010). The tino rangatiratanga flag has been 
flown on the Dunedin Civic Centre building on Waitangi Day since 2008. In September 2010 the South Taranaki District Council decided to hang the tino rangatiratanga flag alongside the New Zealand flag in the Council chambers throughout the year: 'Council Agrees to Hang Maori Flag', Taranaki Daily News, 29 September 2010 (viewed online at www.stuff.co.nz, accessed 18 November 2010).

41 National's Tau Henare was initially dismissive of Pita Sharples' call to fly the flag, and Rodney Hide of Act opposed it: 'Maori Flag on Bridge Call a Stunt - Henare', NZH, 12 January 2009 (viewed online at www.nzherald.co.nz, accessed 18 November 2010). Both have since declared themselves 'relaxed' about the Government's decision: 'Q+A: Rodney Hide Interviewed by Guyon Espiner', 30 August 2009 (http://tvnz.co.nz accessed 2 September 2009); 'Maori Flag Will Gain Meaning in Time, Says Key', NZH, 16 December 2009 (viewed online at www.nzherald.co.nz, accessed 18 November 2010). Despite having been a member of Te Kawariki, Labour MP Shane Jones has criticized the selection of the tino rangatiratanga flag as the national Māori flag, calling it 'Hone's flag' and 'the Maori Party flag', and warning that it could 'further morph into a symbol of dissension and divisiveness.' However, Labour leader Phil Goff has said that Labour 'did not have an issue with the Government's decision'. 'Maori Leaders Clash Over Flag's New Role', NZH, 15 December 2009; 'Unrest Over Maori Flag Decision', Fairfax Media news story, 15 December 2009 (viewed online at www.stuff.co.nz, accessed 18 November 2010); 'Samuels Berates Key Over Flag Deal', Northern Advocate, 16 December 2009 (viewed online at www.northernadvocate.co.nz, accessed 18 November 2010).

42 Research New Zealand, 'Flying the Maori Flag up for Debate', media release, 29 September 2009. The poll surveyed 500 people aged 18 and over, of whom 62 were Māori or Pacific and 130 were aged 18-34. 51\% of those aged 18-34 agreed with flying the flag, as did $53 \%$ of Māori and Pacific people.

43 'Support Strong for Separate Maori Flag', NZH, 4 February 2010 (viewed online at www.nzherald.co.nz, accessed 18 November 2010). The poll surveyed 1002 Māori from the Māori and general rolls.

44 The summaries in the two paragraphs that follow are based on a reading of editorials, letters to the editor, comments on news websites, and blogs. See especially the New Zealand Herald website's 'Your Views' section: 'Do You Support Flying a Maori Flag Above the Harbour Bridge on Waitangi Day?' (www.nzherald.co.nz, accessed 23 July 2009) and 'Should the Tino Rangatiratanga Flag be used on Waitangi Day?' (www .nzherald.co.nz, accessed 20 February 2010). Some minor spelling mistakes have been corrected in quotes taken from the 'Your Views' page.

45 Phoenix (Hamilton East), comment on New Zealand Herald website's 'Your Views' section, 'Do You Support Flying a Maori Flag Above the Harbour Bridge on Waitangi Day?', www.nzherald.co.nz, accessed 23 July 2009.

46 Pragmatist (Titirangi), comment on New Zealand Herald website's 'Your Views' section, 'Do You Support Flying a Maori Flag Above the Harbour Bridge on Waitangi Day?', www.nzherald.co.nz, accessed 23 July 2009.

47 taz (Glendene), comment on New Zealand Herald website's 'Your Views' section, 'Do You Support Flying a Maori Flag Above the Harbour Bridge on Waitangi Day?', www .nzherald.co.nz, accessed 23 July 2009.

48 Pearl (Singapore), comment on New Zealand Herald website's 'Your Views' section, 'Do You Support Flying a Maori Flag Above the Harbour Bridge on Waitangi Day?', www .nzherald.co.nz, accessed 23 July 2009.

49 mbetham (Victoria), comment on New Zealand Herald website's 'Your Views' section, 'Do You Support Flying a Maori Flag Above the Harbour Bridge on Waitangi Day?', www.nzherald.co.nz, accessed 23 July 2009. 


\section{Journal of New Zealand Studies}

50 hinerau (Northland), comment on New Zealand Herald website's 'Your Views' section, 'Do You Support Flying a Maori Flag Above the Harbour Bridge on Waitangi Day?', www.nzherald.co.nz, accessed 23 July 2009.

51 See, for example, the comments of Prime Minister John Key on 'Morning Report', Radio New Zealand National, 15 December 2009: 'You don't see New Zealanders running around objecting if the haka is performed by the All Blacks at a test match. In fact, there's wild outcry when there's suggestions from British sporting journalists every so often that it should be dropped.'

52 See, for example, Shane Jones, 'Standing Room Only For Maori', 26 August 2009, http://blog.labour.org.nz/index.php/2009/08/26/standing-room-only-for-maori, accessed 28 February 2010.

53 'On the Meaning of the Tino Rangatiratanga Flag', 26 January 2009, Aotearoa Independent Media Centre, www.indymedia.org.nz/article/76532/meaning-tino-rangatiratanga-flag, accessed 28 February 2010; also published in October 15th Solidarity Newsletter, no. 10, 1 February 2009. See also the comments on 'Maori Flag to Fly on Waitangi Day', 23 November 2009, http://news.tangatawhenua.com/archives/2042, accessed 20 February 2010); Carwyn Jones, 'Year 170: Tino Rangatiratanga and the Flag', 21 December 2009, http://ahi-ka-roa.blogspot.com/2009/12/year-170-tino-rangatiratanga-and-flag.html, accessed 20 February 2010.

54 The New Zealand Herald columnist Brian Rudman has been arguing since 2007 that the tino rangatiratanga flag should be adopted as New Zealand's national flag: 'We Pinched their Land, Let's Pinch their Flag', NZH, 5 February 2007 (accessed via the Newztext database); 'GI John Needs to Run up the Maori Flag', NZH, 21 January 2009 (viewed online at www.nzherald.co.nz, accessed 18 November 2010); 'Flagging a Change Needn't Cause a Flap', NZH, 16 December 2009; 'Fold Up the Old One and Send it Back to the British Navy', NZH, 5 February 2010. See also John Minto, 'A Flag for All New Zealand', Press (Christchurch), 16 December 2009 (viewed online at www.stuff.co.nz, accessed 18 December 2009). The art historian Hamish Keith is one person who has argued that the United Tribes flag should become New Zealand's national flag: 'Flying the Flag for Unity', NZH, 17 January 2009 (viewed online at www.nzherald.co.nz, accessed 18 November 2010).

55 'Flying the Flag for Unity', NZH, 17 January 2009 (viewed online at www.nzherald .co.nz, accessed 18 November 2010).

56 See, for example, Stephen Levine and Raj Vasil, Maori Political Perspectives: He Whakaaro Maori mo nga Tikanga Kawanatanga, Auckland, 1985, pp.156-58; Raj Vasil, Biculturalism: Reconciling Aotearoa with New Zealand, Wellington, 1988, pp.17-18; Richard Mulgan, Māori, Pākehā and Democracy, Auckland, 1989, pp.135-36.

57 See, for example, 'Flag, Anthem and Even Our Name Under Fire in Book', Sunday Star-Times (SST), 31 January 2010; 'We Need New Anthem and I'll Write it, Says Sharples', DP, 11 February 2010; 'Flag Debate: Maori Split on Need for New Design', NZH, 11 February 2010 (viewed online at www.nzherald.co.nz, accessed 18 November 2010); Malcolm Mulholland, 'Symbols of Nationhood', in Malcolm Mulholland and Veronica Tawhai, eds, Weeping Waters: The Treaty of Waitangi and Constitutional Change, Wellington, 2010, pp.233-49.

58 See, for example, 'Editorial: Two Flags, or a New Flag?', Timaru Herald, 16 December 2009 (viewed online at www.stuff.co.nz, accessed 16 December 2009).

59 Halkyard-Harawira, p.57. See also the comments of Liz Marsden on 'Saturday Morning with Kim Hill', Radio New Zealand National, 6 February 2010; Hone Harawira, quoted in 'Maori Meet to Decide on National Flag', DP, 15 July 2009, and 'Flag, Anthem and Even Our Name Under Fire in Book', SST, 31 January 2010. 
60 Winston Peters interviewed on 'Morning Report', Radio New Zealand National, 15 December 2009.

61 See, for example, Pita Sharples, quoted in 'Room for More than One Flag', 14 July 2009, www.newstalkzb.co.nz/newsdetail1.asp?storyID=160128, accessed 28 February 2010.

62 See, for example, David Lewis, 'Flags, Constitutions, Fleetwood Mac, Zeitgeists . . ', 23 December 2009, http://pundit.co.nz/content/flags-constitutions-fleetwood-mac-zeitgeists, accessed 21 February 2010.

63 Kevin Williams and Jennifer Walpole, The Union Flag and Flags of the United Kingdom, House of Commons Library Standard Note SN/PC/04474, 3 June 2008; Nick Groom, The Union Jack: The Story of the British Flag, London, 2006, pp.291-98.

64 Admittedly, however, the Scottish flag will have a different meaning for people outside Scotland who identify themselves as Scots.

65 On the rohe pōtae of Tūhoe, see Binney, Encircled Lands.

66 Ewan Morris, Our Own Devices: National Symbols and Political Conflict in TwentiethCentury Ireland, Dublin, 2005, especially ch. 7; Ewan Morris, 'One Flag, Two Flags, No Flag, New Flag: Flags on Public Buildings in Northern Ireland', in Brad Patterson and Kathryn Patterson, eds, Ireland and the Irish Antipodes: One World or Worlds Apart? Papers Delivered at the 16th Australasian Irish Studies Conference, Massey University, Wellington, New Zealand, 9-12 July 2009, Spit Junction, NSW, 2010, pp.40-47.

67 Aboriginal and Torres Strait Islander Commission, Recognition, Rights and Reform: A Report to Government on Native Title Social Justice Measures, Canberra, 1995, p.67; Council for Aboriginal Reconciliation, Going Forward: Social Justice for the First Australians, Canberra, 1995, pp.85-86. It was noted in these reports that both flags were already being used for official and ceremonial purposes, including being flown on government buildings on certain days.

68 On the history and official recognition of indigenous Australian flags, see Elizabeth Kwan, Flag and Nation: Australians and their National Flags since 1901, Sydney, 2006, pp.118-19, 133-34; John Gardiner-Garden, Indigenous Flags and Days, Canberra, Department of the Parliamentary Library, Research Note 2002-03, no.4, 20 August 2002.

69 Patrick Dodson, 'Aboriginal Flag a Symbol of Reconciliation', Sydney Morning Herald (SMH), 6 July 1995 (reproduced at www.ausflag.com.au/aboriginal_flag_reconcillation .asp, accessed 28 February 2010).

70 John Howard, media release, 4 July 1995, quoted in Gardiner-Garden.

71 Thomas $v$ Brown and Tennant [1997] FCA 215. Harold Thomas allows health, education, legal and other organizations that help Aboriginal people to use the flag for free, but generally charges a fee to commercial entities: 'Oh Dear: Google Flagged Over Logo Dispute', SMH, 26 January 2010 (viewed online at www.smh.com.au, accessed 18 November 2010).

72 Quoted in Kwan, p.134.

73 Joyce D. Hammond, 'Hawaiian Flag Quilts: Multivalent Symbols of a Hawaiian Quilt Tradition', Hawaiian Journal of History, 27 (1993), p.4.

74 Ibid., pp.1-26.

75 See, for example, 'Viewpoint: Upside-Down Flag is a Reminder of all that Hawaiians Have Endured', Maui News, 2 August 2009 (viewed online at www.mauinews.com, accessed 18 November 2010); 'Muted Commemoration as Hawaii Turns 50 as a State', 21 August 2009, http://abcnews.go.com/US/wireStory?id=8384198, accessed 28 February 2010. 


\section{Journal of New Zealand Studies}

76 “"Original” Flag Raises Debate', Honolulu Advertiser, 12 February 2001 (viewed online at http://the.honoluluadvertiser.com, accessed 18 November 2010); 'What's the Story Behind Hawaii's Flag?', Hawaii Magazine, 21 October 2008 (viewed online at www .hawaiimagazine.com, accessed 18 November 2010).

77 Halkyard-Harawira, p.58.

78 See, for example, 'Maps' (Scott Hamilton), 'For Two Flags', 21 January 2009, http: //readingthemaps.blogspot.com/2009/01/flying-flag-for-ignorance_21.html, accessed 27 February 2010; comment by Myra, 8 February 2010, on Tim Watkin, 'Two Flags Flying - What Does it All Mean?', 6 February 2010, http://pundit.co.nz/content/two -flags-flying-\%E2\%80\%93-what-does-it-all-mean, accessed 27 February 2010, as well as the questions raised in Watkin's post itself. 